\title{
Dynamics of total lipids, total cholesterol, and total immunoglobulins in the blood serum of heifers of different breeds
}

\author{
$V$ Eremenko $^{1}, E$ Rotmistrovskaya ${ }^{2, *}$ \\ 1 Kursk State Agricultural Academy named after I.I. Ivanov, Kursk, Russia \\ 2 Kursk State Medical University, Kursk, Russia
}

\begin{abstract}
The paper studies indices of lipid metabolism, immunoglobulins in blood serum of heifers of different breeds. Black-and-white, Simmental, Aberdeen-Angus, mongrel cattle was selected for this study. Each breed in the group consisted of 10 heads. The study of lipids dynamics in experimental heifers showed, the concentration of lipids gradually increased and by the 5th month reached the maximum values. By the end of the pregnancy on the 9th month, a decrease in the lipid concentration of all the compared breeds was observed. The study of cholesterol dynamics in experimental heifers showed that at 1 month old, the cholesterol level in experimental breed was approximately the same. These were the maximum values of total cholesterol over the entire pregnancy period. At 9 months old, the minimum values of total cholesterol were recorded before calving. The mixed bred analysis showed that a group of Aberdeen-Angus heifers and mongrel animals were characterized by increased blood cholesterol. The study of the dynamics of total immunoglobulins showed that at all periods of pregnancy there were differences in the level of total immunoglobulins in the blood serum of heifers of the studied breeds. By the end of the pregnancy, this indicator was increased. The results of mixed bred studies showed that the mongrel heifers were characterized by a slightly increased content of total immunoglobulins. During the pregnancy period, lower concentrations of lipids, cholesterol and immunoglobulins were typical for blackand-white, Simmental heifers.
\end{abstract}

\section{Introduction}

One of the leading sectors of the agro-industrial complex is meat and dairy cattle breeding. The development program in this area requires an increase in the number of products using advanced selection technologies. It seems fair to say that high productivity of animals depends on how they adapt to different environmental conditions and maintain their homeostasis.

It appears relevant to conduct a thorough study of genetic features and metabolic status in animals of different breeds. Most often, in the study of the metabolic status of animals of different breeds, they resort to the study of blood or its derivatives-serum and plasma. Blood is one of the integration media of the body and it reflects many metabolic processes occurring in organs and tissues, including pathological ones.

One of the components of the physiological status of cattle is the study of lipid metabolism and total immunoglobulins in blood serum. Among the lipid metabolism indicators, lipid and cholesterol concentrations are most important.

Total lipids are a set of blood serum (plasma) lipids. They include neutral fats (triglycerides), cholesterol (free, ether-bound), phospholipids, glycolipids, and free fatty acids. The level of lipids and cholesterols in cattle is an important factor in assessing the absorption of fat by tissues, and therefore an indicator of the quality of meat and milk. Lipids are also universal sources of energy in the animal's body. $[1 ; 2 ; 3]$. There is evidence in the literature that lipids act as participants in the transmission of nerve impulses within the sympathetic nervous system. Lipids influence embryo formation during pregnancy [4].

It is also known that common lipids are the basis of the structures of biological membranes, they form the basis of nervous tissue, accumulate and transport energy, perform a protective role, serve as the basis for a number of biologically active substances (hormones, vitamins, etc.), participate in the interaction of enzymes and substrates on the membranes. Lipids also play a role in maintaining pregnancy and lactation in females. The exchange of lipids during intrauterine development of the fetus is associated not only with the function of the placenta, but also with the metabolic role of the organs of the embryo itself, including the liver.

Cholesterol is the most important structural component of cell membranes. It is involved in the regulation of cell permeability and protects red blood cells from the action of hemolytic poisons. Cholesterol is used in the body for the synthesis of steroid hormones, vitamin D3, and bile acids. The formation of cholesterol occurs in all cells of the body, but the blood receives

\footnotetext{
Corresponding author: rotmistrovskaya.lena@mail.ru
} 
cholesterol, which is formed in hepatocytes and cells of the small intestine. Cholesterol also affects the productive qualities of animals and in different breeds it has distinctive features. Milk breeds have higher cholesterol levels than meat breeds. Some authors note that lipid and fat levels are possibly genetically deterministic [5].

Cholesterol - lipoprotein - is necessary for the body as it participates in cell growth and division, reflects fat metabolism. It also reflects the amount of saturated and unsaturated fatty acids involved in metabolism. It should be noted that it is through the indicators of lipid metabolism, reflecting the course of metabolic reactions at the molecular level, that it is possible to diagnose certain metabolic disorders in the body in a timely manner, and therefore take the necessary measures to eliminate them. Total lipids and total cholesterol are also metabolically important, as they are sources of energy.

Total lipids and total cholesterol play an important role in the liver, providing large amounts of ATP required for gluconeogenesis through beta-oxidation. Cholesterol levels are also subject to changes during pregnancy, as they are involved in the reproductive function of animals [6].

Cholesterol plays a structural role in the cell, affecting cell division and the activity of cell protein receptors. Its level depends on the rate of absorption of bile acids in the liver and the rate of cholesterol excretion by the liver. It follows that during pregnancy, the level of total cholesterol is extremely important for assessing the overall condition of the body. The level of cholesterol in animal tissues depends on its reserves in the brain, adrenal glands and peripheral nerves.Also, a small amount of cholesterol is concentrated in the muscles, fat and connective tissue.

Immunoglobulins are proteins of the body's immune system. They are adaptive molecules that trigger immune responses after recognizing foreign agents. In a healthy body, the function of immunoglobulins is associated with different conformational transitions.[7]

The immune system is not an isolated system in an animal's body. It is functionally connected to all systems in the animal's body. The state of the immune system may be characterized by the content of total immunoglobulins in the blood serum, since they are an important part of the animal's immunity. The content of immunoglobulins is also used to diagnose diseases of different etiology. Besides, immunoglobulins are antimicrobial protection of animals, which is extremely important during pregnancy. They participate in exchange processes as they are an integral part of immunity [8].

Some publications on this issue are ambiguous, since they do not cover the dynamics of lipids, cholesterol and immunoglobulins during the pregnancy of cattle of different breeds. Therefore, the study of these indicators remains relevant because they are necessary to more accurately describe the metabolic status in animals of different breeds. This will allow a deeper study of the processes that occur in the body of cattle during the pregnancy period in different breeds.

\section{Objectives and tasks of the study}

The purpose of this work was to study the dynamics of total lipids, total cholesterol and total immunoglobulins in the blood serum of heifers of different breeds.

In this regard, the following tasks were set:

- to determine the level of total lipids, total cholesterol and total immunoglobulins in the blood serum of black-and-white, Simmental, Aberdeen-Angus and cross breeds (Aberdeen-Angus x Simmental).

\section{Materials and methods}

For this study, the heifers of three breeds were selected the first group - black-and-white, the second group Simmental, the third group - Aberdeen-Angus, the fourth group - mongrel heifers (Simmental x AberdeenAngus). Each breed in the group contained 10 heads. The animals were kept under the same conditions meeting zootechnical standards. The feeding of heifers of different groups was similar. Blood was collected from the tail vein in the fasted state during the period of pregnancy from 1 to 9 months. Total lipid and total cholesterol levels were determined using Sapphire 400 biochemical analyzer. The level of total immunoglobulins was determined by the zinc sulfate method. The results of the study were biometrically processed on a computer using Microsoft Excel.

\section{Results and discussion}

\subsection{Total lipids}

The dynamics of the concentration of total lipids in the blood serum of heifers of different breeds during the pregnancy period is shown in Figure 1.

Figure 1. Dynamics of total lipids in the blood of heifers of

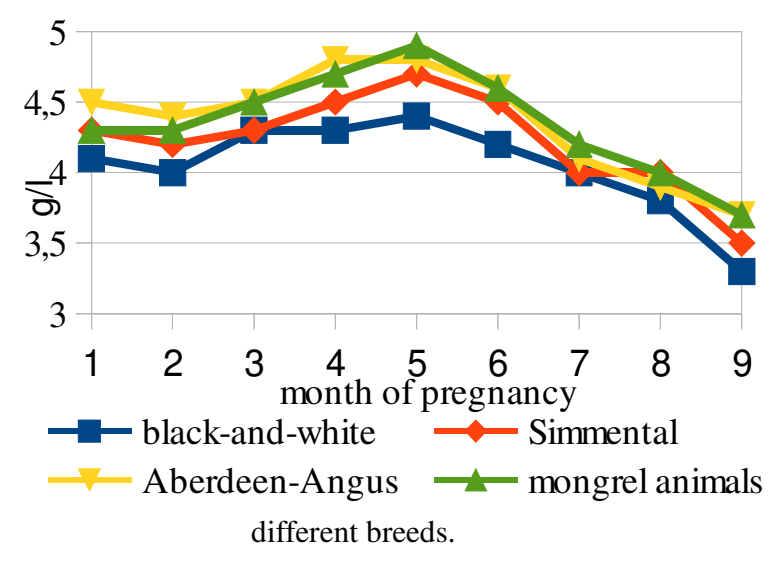

The above results show that at 1 month old, the total lipid level in all groups was within the range from 4.1 to $4.5 \mathrm{~g} / \mathrm{l}$. It amounted to $4.1 \pm 0.12 \mathrm{~g} / \mathrm{l}$ for the black-andwhite breed, $4.3 \pm 0.12 \mathrm{~g} / \mathrm{l}$ - for Simmental, $4.3 \pm 0.12 \mathrm{~g} / \mathrm{l}-$ for mongrel animals, $4.5 \pm 0.11 \mathrm{~g} / \mathrm{l}$ - for Aberdeen-Angus breed. Statistically reliable difference $(\mathrm{P}<0.05)$ were established between the group of black-and-white and 
Aberdeen-Angus animals. By the 2 month of pregnancy, black-and-white heifers had a slight decrease in the concentration of total lipids to $4.0 \pm 0.13 \mathrm{~g} / \mathrm{l}$, Simmental to $4.2 \pm 0.11 \mathrm{~g} / \mathrm{l}$, Aberdeen-Angus - to $4.4 \pm 0.13 \mathrm{~g} / \mathrm{l}$. For mongrel animals, the level of total lipids remained the same. Statistically reliable differences $(\mathrm{P}<0.05)$ were established between the group of black-and-white and Aberdeen-Angus animals at 2 months old.

Starting from 3 months, an increase in the study indicator was observed in all experimental groups of heifers. In the first group during this period, the level of this indicator was $4.3 \pm 0.11 \mathrm{~g} / \mathrm{l}$, in the second group $4.3 \pm 0.13 \mathrm{~g} / \mathrm{l}$, in the third $-4.5 \pm 0.12 \mathrm{~g} / \mathrm{l}$, in the fourth group - $4.5 \pm 0.10 \mathrm{~g} / \mathrm{l}$. The differences between the compared groups were statistically unreliable $(\mathrm{P}>0.05)$. At 4 month, the group of Aberdeen-Angus heifers $(4.8 \pm 0.14 \mathrm{~g} / \mathrm{l})$ and mongrel heifers $(4.7 \pm 0.2 \mathrm{~g} / \mathrm{l})$ differed by relatively high total lipids. A relatively low level of total lipids was recorded in the group of black-and-white heifers $-4.3 \pm 0.14 \mathrm{~g} / \mathrm{l}$ and Simmental heifers $-4.5 \pm 0.12$ $\mathrm{g} / \mathrm{l}$. The differences between mongrel heifers, AberdeenAngus and black-and-white animals were statistically significant $(\mathrm{P}<0.05)$.

At 5 months old, the maximum values of total lipids for the entire study period were noted. In black-and-

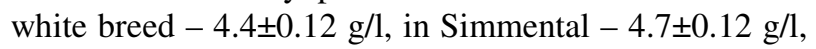
in Aberdeen-Angus - 4.8 $\pm 0.12 \mathrm{~g} / \mathrm{l}$, in mongrel animals $4.9 \pm 0.15 \mathrm{~g} / \mathrm{l}$.

The differences between mongrel heifers, AberdeenAngus and black-and-white animals were statistically significant $(\mathrm{P}<0.05)$. Starting from the 6 month of pregnancy the total lipid levels began to decrease. In black-and-white breed during this period it amounted to $4.2 \pm 0.12 \mathrm{~g} / \mathrm{l}$, Simmental $-4.5 \pm 0.13 \mathrm{~g} / \mathrm{l}$, Aberdeen-Angus - 4.6 $\pm 0.13 \mathrm{~g} / \mathrm{l}$, mongrel animals - $4.6 \pm 0.14 \mathrm{~g} / \mathrm{l}$. The differences between mongrel heifers, Aberdeen-Angus and black-and-white animals were statistically significant $(\mathrm{P}<0.05)$.

At 7 month of pregnancy in black-and-white and Simmental heifers, the concentration of total lipids was at the level of $4.0 \pm 0.13 \mathrm{~g} / 1$, Aberdeen-Angus - 4.1 \pm 0.14 $\mathrm{g} / \mathrm{l}$, mongrel animals $-4.2 \pm 0.12 \mathrm{~g} / \mathrm{l}$. At 7 and 8 months, no statistical reliability was noted. By the end of the pregnancy the heifers of the Aberdeen-Angus breed $(3.7 \pm 0.13 \mathrm{~g} / \mathrm{l})$ and mongrel animals $(3.7 \pm 0.12 \mathrm{~g} / \mathrm{l})$ possessed relatively higher concentrations of total lipids. In black-and-white breed, the level of total lipids was at the level of $3.3 \pm 0.12 \mathrm{~g} / \mathrm{l}$ and in Simmental breed it was lower and amounted to $3.5 \pm 0.12 \mathrm{~g} / \mathrm{l}$.

\subsection{Total cholesterol}

The study of the concentration of total cholesterol in the blood serum of heifers showed that its level in blood is connected with the pregnancy period and pedigree of animals. Figure 2 shows that at the $1^{\text {st }}$ month of pregnancy the level of total cholesterol in black-andwhite breed was $3.0 \pm 0.14 \mathrm{mmol} / \mathrm{l}$, Simmental $-3.1 \pm 0.13$ $\mathrm{mmol} / \mathrm{l}$, Aberdeen-Angus - 3.2 $\pm 0.12 \mathrm{mmol} / \mathrm{l}$, mongrel animals (Simmental $\mathrm{x}$ Aberdeen-Angus) - 3.2 \pm 0.12 $\mathrm{mmol} / \mathrm{l}$.

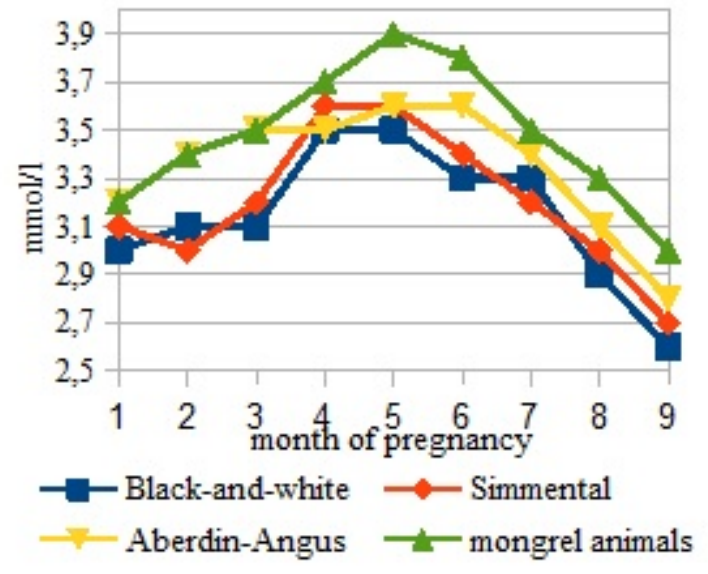

Figure 2. Dynamics of total cholesterol in the blood of heifers of different breeds.

By $2^{\text {nd }}$ month of pregnancy there was an insignificant increase in the concentration of total cholesterol in all experimental groups: black-and-white heifers - up to $3.1 \pm 0.11 \mathrm{mmol} / \mathrm{l}$, Simmental - up to $3.0 \pm 0.12 \mathrm{mmol} / \mathrm{l}$, Aberdeen-Angus - up to $3.4 \pm 0.11 \mathrm{mmol} / 1$, mongrel animals $-3.4 \pm 0.11 \mathrm{mmol} / \mathrm{l}$.

By the $3^{\text {rd }}$ month of pregnancy the Aberdeen-Angus heifers and mongrel animals were characterized by the maximum values of total cholesterol $-3.5 \pm 0.12 \mathrm{mmol} / \mathrm{l}$.

The concentration of total cholesterol in the compared groups was slightly lower: $3.1 \pm 0.13 \mathrm{mmol} / 1$ black-and-white and $3.2 \pm 0.14 \mathrm{mmol} / \mathrm{l}$ - Simmental heifers. The differences between mongrel heifers, Aberdeen-Angus and black-and-white animals were statistically reliable $(\mathrm{P}<0.05)$.

By the $4^{\text {th }}$ month the increase trend in this indicator also remains. Data on the studied groups were as follows: black-and-white heifers - 3.5 $\pm 0.13 \mathrm{mmol} / \mathrm{l}$, Simmental heifers $-3.6 \pm 0.11 \mathrm{mmol} / \mathrm{l}$, Aberdeen-Angus heifers $-3.5 \pm 0.12 \mathrm{mmol} / \mathrm{l}$, mongrel heifers $-3.7 \pm 0.12$ $\mathrm{mmol} / \mathrm{l}$. By the $5^{\text {th }}$ month of pregnancy at all groups of animals the level of total cholesterol in blood increased. Thus, for black-and-white breed the increase made $3.5 \pm 0.12 \mathrm{mmol} / \mathrm{l}$, Simmental - up to $3.6 \pm 0.11 \mathrm{mmol} / \mathrm{l}$, Aberdeen-Angus - up to $3.6 \pm 0.11 \mathrm{mmol} / 1$, mongrel animals - up to $3.9 \pm 0.12 \mathrm{mmol} / \mathrm{l}$.

The differences between mongrel heifers and blackand-white animals were statistically reliable $(\mathrm{P}<0.05)$. These were the maximum values of total cholesterol throughout pregnancy. Further there was a smooth decrease in this indicator.

On the $6^{\text {th }}$ month of pregnancy in the first group of heifers the concentration of total cholesterol made $3.3 \pm 0.13 \mathrm{mmol} / \mathrm{l}$, in the second group - 3.4 \pm 0.12 $\mathrm{mmol} / \mathrm{l}$, in the third $-3.6 \pm 0.11 \mathrm{mmol} / \mathrm{l}$, in the fourth $3.8 \pm 0.13 \mathrm{mmol} / \mathrm{l}$.

After the $7^{\text {th }}$ month of pregnancy there was a decrease in the concentration of total cholesterol in the blood of heifers. In black-and-white breed the level of total cholesterol by this period was $3.3 \pm 0.12 \mathrm{mmol} / \mathrm{l}$, Simmental - 3.2 $\pm 0.11 \mathrm{mmol} / \mathrm{l}$, Aberdeen-Angus $3.4 \pm 0.13 \mathrm{mmol} / \mathrm{l}$, mongrel heifers $-3.5 \pm 0.12 \mathrm{mmol} / \mathrm{l}$. The specified differences between the compared groups were statistically unreliable $(\mathrm{P}>0.05)$. 
By the $8^{\text {th }}$ month of pregnancy the tendency to decrease in total cholesterol remained: black-and-white breed - 2.9 $\pm 0.12 \mathrm{mmol} / \mathrm{l}$, Simmental - 3.0 $\pm 0.11 \mathrm{mmol} / \mathrm{l}$, Aberdeen-Angus - 3.1 $\pm 0.13 \mathrm{mmol} / \mathrm{l}$, mongrel animals $3.3 \pm 0.12$. mmol/l. The differences between mongrel heifers and black-and-white animals were statistically reliable $(\mathrm{P}<0.05)$. On the $9^{\text {th }}$ month of pregnancy before calving the minimum values of total cholesterol are recorded. The level of total cholesterol for the black-andwhite breed was $3.6 \pm 0.12 \mathrm{mmol} / \mathrm{l}$, Simmental $-2.7 \pm 0.11$ mmol/l, Aberdeen-Angus - 2.8 $\pm 0.13 \mathrm{mmol} / \mathrm{l}$, mongrel animals $-3.0 \pm 0.12 \mathrm{mmol} / \mathrm{l}$. The differences between mongrel heifers and black-and-white animals were statistically reliable $(\mathrm{P}<0.05)$. The mixed bred analysis showed that Aberdeen-Angus heifers and mongrel animals differed in the increased level of total cholesterol in blood.

\subsection{Total immunoglobulins}

The results of the studies showed that at all periods of pregnancy there were differences in the level of total immunoglobulins in the blood serum of heifers of the studied breeds. At 1 month old, in terms of the level of total immunoglobulins, Aberdeen-Angus heifers $(19.3 \pm 1.3 \mathrm{mg} / \mathrm{ml})$ were superior to black-and-white cows (18.7, $19.3 \pm 1.5 \mathrm{mg} / \mathrm{ml})$, Simmental $(18.9 \pm 1.4 \mathrm{mg} / \mathrm{ml})$ and mongrel animals $(18.6 \pm 1.4 \mathrm{mg} / \mathrm{ml})$.

By the 2nd month of pregnancy, total immunoglobulins increased in black-and-white breed to $19.0 \pm 1.2 \mathrm{mg} / \mathrm{ml}$, Simmental - to $19.3 \pm 1.4 \mathrm{mg} / \mathrm{ml}$, Aberdeen-Angus - to $19.5 \pm 1.6 \mathrm{mg} / \mathrm{ml}$, mongrel animals - to $19.1 \pm 1.5 \mathrm{mg} / \mathrm{ml}$. There were no reliable differences between the studied breeds at 1 and 2 months old.

At 3 months old, mongrel animals exceeded all compared breeds in terms of total immunoglobulins $20.2 \pm 1.3 \mathrm{mg} / \mathrm{ml}$. In black-and-white breed this indicator was $19.4 \pm 1.3 \mathrm{mg} / \mathrm{ml}$, Simmental - $19.2 \pm 1.5 \mathrm{mg} / \mathrm{ml}$, Aberdeen-Angus - 19.7 $\pm 1.4 \mathrm{mg} / \mathrm{ml}$.

At 4 months old, this trend continued. Mongrel animals had the highest level of total immunoglobulins $21.2 \pm 1.3 \mathrm{mg} / \mathrm{ml}$. The lowest indicators were typical for black-and-white breed $-19.2 \pm 1.12 \mathrm{mg} / \mathrm{ml}$.

By the 6th month of pregnancy, the cross bred differences in the level of total immunoglobulins were as follows: black-and-white $-20.3 \pm 0.12 \mathrm{mg} / \mathrm{ml}$, Simmental - 20.9 $\pm 0.13 \mathrm{mg} / \mathrm{ml}$, Aberdeen-Angus - 24.1 \pm 0.11 $\mathrm{mg} / \mathrm{ml}$, mongrel animals $-24.5 \pm 0.12 \mathrm{mg} / \mathrm{ml}$.

The differences between Aberdeen-Angus heifers and black-and-white animals were statistically significant $(\mathrm{P}<0.05)$. The $7^{\text {th }}$ month of pregnancy was characterized by statistically significant differences $(\mathrm{P}<0.05)$ between Aberdeen-Angus $\quad(23.8 \pm 0.14 \quad \mathrm{mg} / \mathrm{ml}), \quad$ mongrel $(24.1 \pm 0.12 \mathrm{mg} / \mathrm{ml})$ and black-and-white animals $(20.1 \pm 0.11 \mathrm{mg} / \mathrm{ml})$. The maximum values were noted at 8 months old: black-and-white breed $-20.8 \pm 1.2 \mathrm{mmol} / \mathrm{l}$, Simmental breed - 21.7 $\pm 1.4 \mathrm{mmol} / \mathrm{l}$, Aberdeen-Angus $24.6 \pm 0.12 \mathrm{mmol} / \mathrm{l}$, mongrel animals $-25.1 \pm 1.3 \mathrm{mmol} / \mathrm{l}$. The differences between mongrel heifers, AberdeenAngus and black-and-white animals were statistically significant $(\mathrm{P}<0.05)$. By the end of the pregnancy this indicator made $21.3 \pm 1.3 \mathrm{mmol} / \mathrm{l}$ for black-and-white breed, $22.6 \pm 1.5 \mathrm{mmol} / \mathrm{l}$ for Simmental breed, $25.2 \pm 1.2$ $\mathrm{mmol} / \mathrm{l}$ for Aberdeen-Angus breed, $25.3 \pm 1.3 \mathrm{mmol} / \mathrm{l}$ for mongrel animals. The results of cross bred studies showed that mongrel heifers were characterized by a slightly increased content of total immunoglobulins.

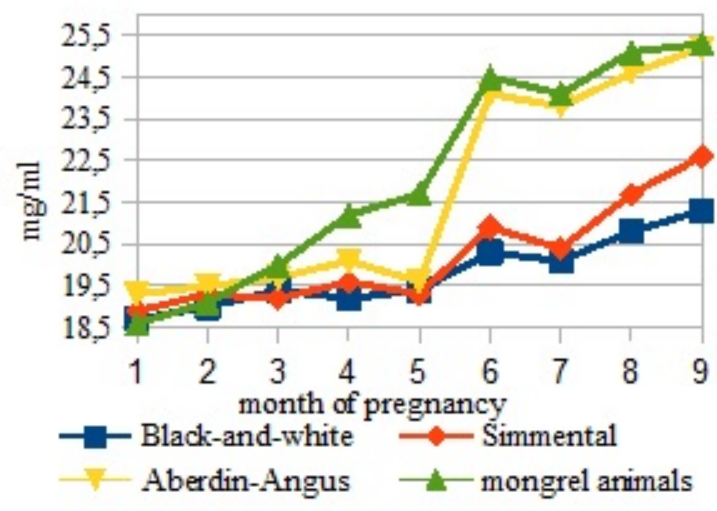

Figure 3. Dynamics of total immunoglobulins in the blood of heifers of different breeds.

\section{Conclusion}

1. The concentration of total lipids depends on the pregnancy period of heifers and their breed. With an increase in the pregnancy period, the level of total lipids in the blood increases by the $5^{\text {th }}$ month, followed by a decrease by the end of the pregnancy period. Higher values of this indicator are noted in heifers of the Aberdeen-Angus breed and in mongrel animals (Aberdeen-Angus x Simmental).

2. The concentration of total cholesterol depends on the pregnancy period of heifers and their breed. With an increase in the pregnancy period, the level of total lipids in the blood increases by the $5^{\text {th }}$ month, followed by a decrease by the end of the pregnancy period. Higher values of this indicator were noted in mongrel animals (Aberdeen-Angus x Simmental).

3. The concentration of total immunoglobulins depends on the pregnancy period of heifers and their breed. With an increase in the pregnancy period, the level of total lipids in the blood increases by the $6^{\text {th }}$ month, followed by a decrease by the end of the pregnancy period. Higher values of this indicator are noted in heifers of the Aberdeen-Angus breed and in mongrel animals (Aberdeen-Angus x Simmental).

\section{References}

1. N.S. Motuzko, O.V. Khvostova Research of young scientists in solving livestock problems: Collection of articles. III International Scientific and Practical Conference, Vitebsk, pp. 172-173 (2003).

2. Yu. N. Shamberev Effect of hormones on the metabolism and productivity of animals. (Moscow: Kolos, 1975)

3. J.C. O'Kelly Austral. J. Biol. Sci. 21(5), 10131024, (1968) 
4. A.A. Aliev Lipid exchange and productivity of ruminants. (Moscow: Kolos, 1980)

5. V.I.Eremenko, Sein O.B. Metabolic status, nonspecific resistance and their correction in cattle (Kursk: Business printing, 2011).

6. Machal L., Chladek G., Zizlavsky J. J. anim. Feed Sc., 8 (2), 209-221 (1999).

7. D. R. Burton, Molecular Immunology. 22(3), 161-206 (1985)

8. V. H.Brungardt, R .W. Bray, W. C. Hoekstra, J.Amer. Sci. 22(2), 326-329, (1963)

9. P.D. Fedorov, Collection of scientific articles. Moscow Veterenary Academy. 65, 45-46, (1973)

10. Z. R. Vlahcevic, P. B. Hylemon The liver, Biology and Pathobiology (N.-Y.: Raven press, 1994) 